\title{
Hérnia perineal em ovelha gestante - relato de dois casos
}

Vanessa Peixoto de Souza", Pollyanna Cordeiro Souto, Diogo Diógenes Medeiros Diniz, Robério Silveira de Siqueira Filho, Fábio Eduardo Campelo de Borba Maranhão, Adriano Machado de Souza, Mayumi Santos Botelho Ono, Jefferson Ayrton Leite de Oliveira Cruz, Huber Rizzo, Janaina Azevedo Guimarães

Ambulatório de Grandes Animais, Hospital Veterinário do Departamento de Medicina Veterinária, Universidade Federal Rural de Pernambuco (UFRPE), Recife, PE, Brasil

*Autor correspondente

e-mail: vanessa.peixoto.vet@hotmail.com

\section{Resumo}

A hérnia perineal é resultado do enfraquecimento e separação dos músculos e fáscias que envolvem o diafragma pélvico, permitindo que o conteúdo retal, pélvico ou abdominal desloque a pele perineal. Relatos desta condição em pequenos ruminantes são escassos. 0 presente trabalho descreve dois casos de hérnia perineal em ovelhas gestantes, da mesma propriedade, ambas de segunda cria e no final da gestação. Os animais não tinham parentesco. No primeiro caso relatou-se aumento de volume na região perineal que evoluiu gradativamente durante três meses. Ao exame físico, observou-se parâmetros fisiológicos, contudo havia a presença de hérnia perineal bilateral e facilmente redutível. A ultrassonografia revelou um feto vivo. 0 animal foi encaminhado para casa sob observação. Depois de seis dias retornou, tendo parido um feto fêmea vivo, no entanto permanecia com a hérnia perineal, além de mucosas congestas, contrações abdominais, secreção vulvar serosanguinolenta e fétida e tecido desvitalizado na região caudal do saco herniário. Ao exame ultrassonográfico foi visualizado útero aumentado compatível com puerpério fisiológico. Foi realizada herniorrafia bilateral, sendo observado o útero ocupando o saco herniário esquerdo e reto e gordura pélvica ocupando o antímero direito. Também apresentava tecido desvitalizado no saco herniário esquerdo, que foi excisado durante o procedimento, e uma fístula vaginal. Foi realizada antibioticoterapia e terapia analgésica pós-cirúrgica, no entanto, ocorreu deiscência de pontos e necrose na região perineal, além de metrite, com o animal vindo a óbito. À necropsia foi observada peritonite serofibrinosa. 0 segundo animal possuía histórico de apatia, inapetência e decúbito prolongado, além de aumento de volume na região perineal. Apresentava tremores musculares, aumento de volume bilateral na região perineal, redutível, sendo mais perceptível quando o animal estava deitado, mucosas congestas e atonia ruminal. No exame ultrassonográfico foram observados dois fetos vivos. Os achados laboratoriais revelaram leucocitose 
por neutrofilia, hiperfibrinogenemia, glicemia normal, porém presença de cetonúria, indicando também um quadro de toxemia da prenhez. 0 animal ficou internado no Hospital Veterinário do Departamento de Medicina Veterinária da Universidade Federal Rural de Pernambuco, onde foi iniciado o tratamento para toxemia da prenhez, sendo utilizado propilenoglicol (VO) e gluconato de Ca (SC). Após seis dias internada, entrou em trabalho de parto. Devido ao quadro clínico, foi realizada cesariana obtendo-se dois fetos vivos. Após a cesariana, a hérnia reduziu, não sendo necessária intervenção cirúrgica, com o animal recebendo alta clínica. Neste caso não foi possível estabelecer qual o conteúdo da hérnia, sugerindo-se a presença do útero gravídico. Foi relatado que a propriedade possuía áreas íngremes, onde os animais pastavam, o que pode ter contribuído para o aumento da pressão no diafragma pélvico e consequente hérnia perineal nas duas ovelhas prenhas. Apesar de rara, a hérnia perineal em ovinos pode ser grave e levar o animal a óbito. Aparentemente, a gestação, associada a condições ambientais, pode ser um fator predisponente. 